\title{
The process of developing new competences: a case study at a family agricultural production unit
}

\author{
Uiara Bandineli Montedo ${ }^{\mathrm{a}}$, Julia lssy Abrahão ${ }^{\mathrm{b}}$ \\ a*Universidade de São Paulo, São Paulo, SP, Brasil, uiara.montedo@usp.br \\ 'Universidade de Brasília, Brasília, DF, Brasil.
}

\begin{abstract}
This article addresses the difficulties faced by farmers who implement new production methods on their land. We discuss the nature of the new competences that farmers must develop, highlighting the complexities of the means they use, the difficulties they confront in this process, and the strategies farmers develop in consonance with the practical knowledge of their profession. The method used includes elements of Ergonomic Work Analysis combined with a case study. Le Boterf's model of the process of constructing competences is used to support the data analysis. The discussion is organized based on an analysis of the evolution of consolidated competences that are re-elaborated for a new agricultural production. The analysis of the strategies and operational modes is introduced, and their contribution to the development of new competences is noted, thus enriching the model proposed by Le Boterf. It is essential to understand the cognitive processes, strategies, and operating modes involved in the development of competences. This procedure provides mechanisms that preserve the opportunity for observation of significant variables in managing variability to be included in the transformation or evolution of work situations and to define the activities that workers will perform.
\end{abstract}

Keywords

Competences. Agricultural ergonomics. Cognitive ergonomics. Family farming.

\section{Introduction}

Through a case study, this article makes explicit the genesis and nature of new competences developed by farmers when introducing new modes of production. In this context, an attempt is made to show the complexity of the operating modes developed, the difficulties encountered in this process, and the strategies farmers develop in line with the experience they acquired in the exercise of their profession.

Different authors in the area of ergonomics have pored over these themes seeking to translate competences conceptually. Maggi (2004) defines competency as the translation of knowledge and experience into action in the course of a continuous learning experience. According to the author, it includes knowing how to interpret, knowing how to evaluate, and knowing how to intervene, although it is in work activity that competences are constituted. Montmollin (2001) defined competences as being stabilized sets of knowledge and know-how, of standardized behavior, standardized procedures, and types of reasoning, that can be put into practice without recourse to new learning, and that make concrete and structure acquisitions from their professional history.

Abrahão et al. (2009, p. 158) stated that understanding competences

[...] allows us to comprehend human activity and explain how workers avoid making errors, anticipate dysfunction, how they correct for it, which stages of the task they consider most important, how they deal with unexpected events, detect and diagnose problems, and organize their activities in both normal and critical situations. 
The authors thus include the concept of dynamic, evolutionary activity which is the result of professional history.

Leplat (2001) points out some of the features characteristic of these competences:

- They are finalized and are characterized by applying them to achieve an objective; competences are always competences to perform a task or set of tasks; thus competences are operational and functional.

- They are acquired through learning processes which can be distinct, rationally guided, as in the case of instructions, training centers, schools, and learning by actions;

- They are organized in units coordinated to achieve an objective;

- They are an abstract, hypothetical concept since they cannot be observed; what are observed are manifestations of competences.

Weill-Fassina \& Pastré (2007) add additional characteristics of competences, distinguishing their modalities and the conditions necessary for their manifestation:

- People are not born competent, but become competent; i.e., there is development due to training and/or professional experience;

- They are made more or less explicit by workers; explicit when easily verbalized and reported, tacit or incorporated when they are manifested above all in action;

- They are inscribed by organizational conditions.

Another important feature of competences is pointed out by Dejours (2012, p. 49): “[...] performance precedes, competency follows". The author explains that only after achieving success with a new performance that it is possible to reconstitute the route traversed between the event and the effective operating mode (Dejours, 2012).

Different authors (Le Boterf 1995, 2004; Montmollin, 2001; Maggi, 2004; Abrahão et al., 2009; Dejours, 2012; Weill-Fassina \& Pastré, 2007) converge with respect to the fact that competences manifest in activities and they do not exist outside the context of being used.

Competences refer to people's potential for performing an activity at a given moment in a certain situation. They make workers' knowledge and ability operational in the form of concrete actions. (Abrahão et al., 2009, p. 158)

It is worth emphasizing two important characteristics at the heart of the concept of competences: they do not crystallize, they transform in function of the demands of context. Thus they are dynamic and their evolution depends on the flexibility that work organization allows workers during their decision-making process, at the time of their actions (Abrahão et al., 2009).

Ergonomic work analysis seeks to comprehend work with a view to transforming it, but it also provides support so that the introduction of new technologies can occur based on the demands imposed by the new context. Identifying competences that are transferred and mobilized by workers allows us to comprehend their development and genesis and is thus favorable to working conditions and the process of creating new learning.

It is possible to identify the representations workers have of their jobs by studying the competences that they mobilize to act. From this perspective, identifying competences required to perform tasks can be one of the ways of comprehending human activity.

Although different authors define the characteristics and the mechanisms mobilized in developing competences, rarely are they concerned with explaining the genesis of competences. Montmollin (2001) stated that usually ergonomists tend to neglect observing competence at the time it is generated, contenting themselves with analyzing the behaviors established a posteriori.

It is in this context that we discuss the model adopted as a theoretical framework for data analysis as well as the methodology and the research procedures. The results are shown and discussed in two parts: the first examines the evolution of competences and in the second, the contribution of operational strategies and operational methods in the development of new competences. Finally, we discuss how, by analyzing the activity, it is possible to appreciate the richness of the cognitive processes developed by the farmer to build new competences. This knowledge enables driving future transformations in work situations, in order to preserve the aspects that fit and guide the evolution of which is not completely adequate.

\section{Consolidated competences and the bases for acquiring new competences}

The explanatory model adopted in this study was proposed by Le Boterf $(1995,2004)$. The author starts with the supposition that competence manifest in action and there is no competence outside the context of its use. This was later corroborated by Weill-Fassina \& Pastré (2007). From this perspective, he is innovates in proposing the concept of "resources" to explain the sets of know how mobilized in creating competences, including 
the social know how: the repertory of knowledge and know how at a person's disposal is made up of more than theoretical or procedural knowledge that can be mobilized in a particular work situation. There is also a social component composed of codes, social representations, values, and statures, in addition to the relational attitudes adapted to the social prescriptions of a group or a particular culture (Le Boterf, 1995).

Le Boterf (1995) emphasizes that the process of consolidating a competence is permeated by the mobilization of resources, i.e., it is in practice and the subsequent expansion of the repertory of resources that these resources gain the status of competences. This mobilization has a particularity; it is not a simple application, but rather a construction. The author calls this know-mobilizing. (Figure 1).

"A competence is a know-acting since it presupposes that people know how to link instructions and not just apply them in isolation" (Le Boterf, 1995, p. 35).

Of a combinatory nature, a competence is an overlapping of several ingredients that have been selected, most often with discernment. It is not simply the addition of partial knowledge

(Le Boterf, 1995, p. 23-24). The author calls this know-integrating. "A competence is the ability to know how to integrated diverse, heterogeneous knowledge to finalize it in undertaking activities." (Le Boterf, 1995, p. 21).

The author emphasizes that for know-integrating, the coherence of the arrangement of the pertinent elements selected by people from among the resources at their disposal is not a function of a given situation, but rather the representation that the operator creates from the situation; representations

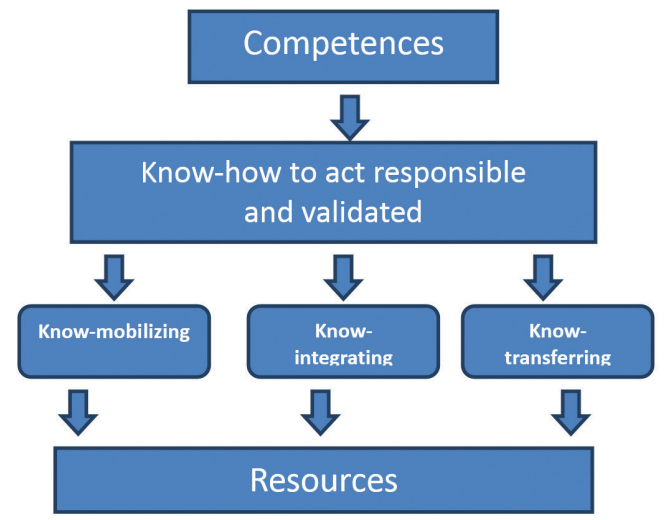

Figure 1 - Le Boterf's Competency Model. Source: adapted from Le Boterf, 1995 and cognitive styles are not identical from one person to another (Le Boterf, 1995).

Le Boterf (1995) further introduces knowtransferring as one of the processes of competence consolidation, which is related to the individual's capacity to transfer the resources mobilized and integrate them into the new work situation. Nevertheless, in this process, s/he will retain some of the characteristics of the earlier work situation. Know-transferring is thus a search to generalize the competence created for a certain configuration in the work situation, and the individual can deal with it based on already utilized and validated resources, adapting them to the new situation, which is similar but distinct from the earlier situation.

Thus, the process of building competency takes place by means of action, mobilization, integration, and transferal of resources of a declarative and/or procedural nature to a given work situation. The use and transformation of a person's resources becomes a competence when it is put into action. Nevertheless, to acquire competences, it is not enough for individuals to know how to select those which are pertinent to a given work situation from their repertory of resources. It is necessary to organize them and use them to accomplish a professional activity, resolve a problem, or carry out a project. Faced with a problem to be resolved or a project to be accomplished, cognitive architecture specific to the needed competence is created.

There remains another important issue related to the role of self-image in the creation of competence. Le Boterf (1995) states that mobilizing the relevant knowledge or know-how in a situation is not related just to cognitive resources, knowledge or know-how. Mobilizing resources presupposes trusting that they exist, trusting in one's ability to use them in an effective way, and in their potential for evolution. A negative self-image or a lack of confidence can be a source of inhibition and incompetence When individuals face a new situation with a lack of confidence in their competence and if they are overcome by fear of being judged related to unsatisfactory performance,

[...] they will have the tendency to banalize the newness of the situation, and return prematurely to already-known answers, to protect themselves by repeating that which they already know how to do

(Le Boterf, 1995, p. 71).

This social dimension of human activity is corroborated by Darré (1989, p. 11), when he says

[...]making a judgment about what is good to do, about the way of recognizing oneself in a certain situation, of describing and evaluating it, even if 
as individuals, people are nonetheless constrained by the social and culture as means of conceiving things.

In the case of agricultural activity, developed in a dynamic context rich in unforeseens, these non-routine situations are extremely frequent (Montedo \& Sznelwar, 2008; Montedo \& Sznelwar, 2009). A positive self-image is a determinant in acquiring new competences in the farming profession.

Another study of the construction of competences done by Jourdan (1989) with winegrowers in France, shows "different sources of knowledge and the way they are mobilized by the individual". In doing so, the author distinguishes "knowledge from the farmers' own experience, whether from a single past experience or an accumulation of experiences" from those that come from the "vulgarization of technical knowledge and others that farmers get from observing, listening and later implementing their knowledge" (Jourdan, 1989). The author suggests that the competence of farmers in work situations is based on a cycle that he calls competences of observation, synchronization and research. The competence of observation is an ability that the farmer develops in observing the different production processes that occur simultaneously in the production unit, however, with different spatial and temporal frameworks, which allow them to identify the features of development of the production cycle of each process. This competence provides subsidies for defining the priority and sequencing of actions; Jourdan (1989) call this synchronization competence. Research competences refer to the use of distinct procedures depending on the nature of the problem faced (Jourdan, 1989).

Comparing Jourdan's (1989) and Le Boterf's $(1995,2004)$ models we see that even when Jourdan relates the source of knowledge to farmers, he associates them with their forms of use, i.e. with the building of competence. Thus he does not explicitly consider the declarative knowledge that farmers have. If we take as a reference the notion of resources Le Boterf introduced, we see that individuals also include the theoretical (or declarative) theories available to them in formulating these resources. They may not be used for work activities, but are stored as knowledge that makes up an individual's resources. For farmers, this knowledge would be, for example, the learning acquired during the stages of classic training wherein the transition from theory to practice does not always occur.

Another aspect led the authors to prioritize Le Boterf's model $(1995,2004)$ as a theoretical framework in light of the discussion of the empirical data: we considered that Jourdan's model (Jourdan, 1989) was generated based on analysis of farmers' work in producing fruits, which is a perennial crop for the production unit. With perennials, long term cultivation practices and the effects of an activity done today can only manifest in the long term. This situation is substantially different from the one we analyzed, since animal production cycles are relatively shorter and the effects do not delay in manifesting. Moreover, because it is a culturally ancestral production in the region studied, one can assume that knowledge is also ancestral, transmitted from generation to generation. Another factor that reinforces the choice of the Le Boterf model lies in the fact that the situation studied involves a new type of production and thus farmers were obliged to develop new competences.

That is the reason this article takes Le Boterf's $(1995,2004)$ explanatory model as a conceptual basis to illustrate the process of competence construction. This model will be enriched by complementary concepts, notably operating strategy, operating mode and representations for action (Teiger, 1993; Abrahão et al., 2009).

Abrahão et al. (2009) define operating strategies as a regulation processes workers use to organize their competences in response to the demands of the task and their personal limits. In this sense, it can be said that they result from action plans elaborated and re-elaborated in the process of work regulation. Operating strategies involve cognitive processes such as attention, categorization, problem solving and decision making, resulting in a set of actions called an operating mode.

\section{Methods}

The data presented originated from an ergonomic intervention carried out in the western region of France, in the department of Mayenne, at ten family agricultural units which produce cow's milk. The farmers' request to empower their role so that each project include the specific objectives of the families, among them, improved working conditions and bringing their family-farm production units into conformance with the environmental rules of the Common Agriculture Policy of the European Economic Community. The proposed method combined days of observation and analysis alternating with training-action days on the organization of family farming work (Montedo \& Sznelwar, 2008; Montedo \& Sznelwar, 2009). The method adopted was supported in Ergonomic Work Analysis (EWA) principles, as proposed by Guérin et al. (2001). 


\subsection{Procedures and tools}

The ergonomic work analysis lasted for seven months, and generated a set of data for the ten production units. Nonetheless, to deepen the discussion about the process of creating new competences, it was decided to treat the data from one of the production units in this paper.

The choice of the production unit to be analyzed was due to the introduction of a new type of production - goat's milk - alongside the main type of production, cow's milk. The data are of qualitative nature.

The observation and analysis days conformed to the daily work cycle that began with early milking at 6 a.m. and could last until 8 p.m. The farmers' activities were recorded with the aid of an observation grid, pencil and paper, and these notes attempted to follow the development of actions in space, time and chronology. This tool allowed for the creation of activity logs, developed as activities unfolded during the course of the observation day. These logs were used as an aid in the review sessions, making it possible to reconstruct stories based on significant occurrences during the day's observations. These were considered significant due to their real or potential consequences for work organization, efficiency in production and the health of the team of workers.

Breaks between activities (breakfast, coffee breaks, etc.) were used to review observations with the farmers to qualify the systematic observations. Due to the short time allotted for the days of observation and work analysis at each production unit (one day and part of a night), this methodological strategy was adopted as a way to recover the representations of the activities and to make explicit the genesis of the operating modes used to accomplish the different tasks.

At the end of the work day semi-structured interviews were done to explore more deeply the activities from the day of observation. This was, important to a better comprehension of the operating modes. These questions referred to choices made earlier at the production unit and their consequence for work organization, the nature of the competences mobilized by the farmer, the consequences of introducing a new type of production, as well as development projects at the unit.

Thus, the results presented and discussed in the following section are the product of an a posteriori reflection on this set of data, about the process of constructing new competences needed to meet the objectives of the new production. Based on the semi-structured interview and questions, stories emerged and based on these, it was possible to identify elements of the process of developing these new competences.

\section{Results}

\subsection{The evolution of a competence for new agricultural production}

The farmer couple produced only cow's milk at the family farm production unit, but needed to increase their income. So they decided to install a production of goat's milk, since at the time, the cooperative in the region was seeking farmers disposed to begin this type of production, new to the region. They decided to begin production with 30 goats. The couple already had experience in producing cow's milk, but realized they needed new competences to practice this new kind of production.

The veterinarian told the farmers at the start of this activity that they could not use the drugs they normally used for cows, but would have to buy more expensive drugs, specific to goats. The farmer bought the goat-specific drugs and used them, but they did not function well; he stated that the drug hadn't cured a single goat. Moreover, he discovered that (differently from what the veterinarian advisor told him) that goats do get milk fever (hypocalcimia - a post- partum calcium deficiency, just like cows). Symptoms of milk fever in cows are: first the standing animals get muscular tremors in the head and appendages, don't want to move and won't eat; they can become agitated and experience paralysis of the head, teeth grinding and later, rigidity in the hind hoofs - the animals fall and remain lying down for long periods with their heads turned toward their flanks; consciousness diminishes, the hoof rigidity disappears, the appendages are flaccid and extremely cold; digestive changes such as ceasing rumination and tympanism (intense production of stomach gases) are frequent (Oliveira, 2013). The diagnosis of this disease is based on clinical signs and animal's history and is confirmed by a positive response to treatment. The farmer already had the competence that allowed him to differentiate the behavior of cows when they have milk fever, from that of goats with the syndrome. In his daily work observing the goats, he realized that differently from cows, goats can get up before dying. In creating this new representation of his animals' behavior, he was able to develop differentiated operating strategies for managing the goats, which allowed him to perceive the masking of the symptoms. 
The farmer's operating strategy was to use the same drugs that he used for cows in lower doses, and he was able to save two of the three goats that had symptoms. This example illustrates the process of mobilizing resources related to know-transferring. From this perspective, the validated strategies rose to the status of competence.

This acquisition was very important to the success of the new goat-raising venture, since the simultaneous loss of three breeders from a total of thirty would heavily impact productivity and could have serious consequences at the start of production. Thus, one can infer that this new competence was the result of his mobilizing his knowledge of bovine milk production, which was then integrated and transferred to "goat milk production."

This example allows us to understand how the farmer mobilized, integrated, and transferred the resources available to him related to milk fever seen in cows, despite:

- The differences in behavior between cows and goats;

- The difference in size between the animals; and;

- Prioritizing his personal knowledge over the instructions given by the technicians, fitting the prescription to the demands of the task.

This example allows us to hypothesize that the ability to mobilize resources coming from his experience, to integrate them into new situations, relate them to the new reality, and adapt them in a way pertinent to the demands of the new work situation, makes explicit each of the stages in the process of developing competence during his decision-making process. This example is also close to the findings of Jourdan (1989) about competence based on experimentation, reinforced by the fact that the farmer gives preference to knowledge coming from his own experience over that coming from other sources.

\subsection{Operating strategies and their contribution to the acquisition of new competence}

Data from this same production unit allow us to learn how the farmer implemented an identification system for the goats in order to reduce the risks of milking those he shouldn't. Milk from goats that are on the verge of delivering kids, or those who have just delivered, must be separated. This procedure is aimed at preventing a disease transmitted via the colostrum, caprine arthritis encephalitis. Thus, to avoid contaminating the other milk deposited in the tank, compromising its quality and thus payment, this milk is separated from the rest and thrown out. In the milking room the farmer uses cords tied on the goat's hooves to identify those who should be milked separately.

To this, the farmer added another identification system by making a temporary mark on the animals' backs. This system is used to identify animals that the farmer must milk even though he has to throw out the milk. This is because some of the goats that stop giving milk during gestation, and can lose the custom of going to the milking room. Right after giving birth, the farmer puts ink on the animal's back to identify them more easily in the stable and see which animals don't move toward the milking room. Thus, he can identify which goats have given birth and need to be retrained to move to the milking room along with the others.

These identification systems used for different, though complementary, purposes become a set of procedures that allow the farmer to be sure of his activities with the herd. Thus he reduces the risk of incorrect interventions, increases confidence in his work system and assures the quality of the results.

The goat identification systems are operating strategies: initially the farmer ties cords on the breeders' hooves when the teats begin to show signs of tumescence and right after giving birth, he applies the temporary ink markers. The farmer reports that goats have difficult temperaments, and differently than cows, they eat everything they see. Thus, after reflecting on a goat identification system that is resistant to their "voracious appetite," the farmer opted to tie a cord on one of the goats' hooves, a solution which was both resistant to the animals' bad habits and relatively low cost. This practice is an adaptation of the cow marking system, common among milk producers in the region who use a red ribbon tied with velcro to the hooves, identifying which cows need to be milked separately. Thus, the cord system for goats is a version of the red ribbon system for cows, but the ribbon is tied with a knot to better resist the goats' efforts to remove them.

In practice, it is a little more complicated - combining the two systems relates to at least three variables that are observed by the farmer:

- Goat behavior: the goats that dry up during gestation and lose the habit of going to the milking room are identified with a temporary mark on their backs only after giving birth, so that the farmer doesn't "forget" them in the stable and can retrain them to twice daily milking. 
- The priority points for information collected on the animals' bodies according to the task that is being carried out: temporary markers on the goats' backs are used mainly to identify goats that perhaps have lost the habit of going to the milking room (those who had given birth). Since the farmer takes a higher position when herding the goats into the waiting area prior to milking, his most reliable information is what he can see on the animals' backs and not in his files. On the other hand, when he is in the milking room his work plan is at waist height and the teats are then the priority area to see as he connects the milking machine. In this situation, the most reliable vantage point is the animals' hooves instead of their backs, because they are closer to the teats.

- The appearance of the goat teats in relation to their physiological condition: when the goats "dry up" during gestation, their teats are withered. When close to delivery date, their teats become tumescent again. When the goat has not yet delivered, the farmer ties a cord on the hoof, and after delivery he will put the temporary mark on her back. Thus when he sees a goat with a cord on the hoof, he also looks at her back. If she doesn't have the back mark, he knows she should not be milked, since she has not yet delivered, and he also knows to observe her since she is close to delivery date and might need help with delivery. If the goat has a cord on the hoof and the temporary back marking, he knows that she has delivered and her milk should be separated. At the end of the period in which her milk is no good for sale, which lasts 3 to 4 days after delivery, the farmer removes the cord and starts to milk normally. This goat will still have the temporary back mark for 3-4 weeks, which serves to remind the farmer not to "forget" this animal in the stable until she has relearned the habit of going to the milking room with the others.

The data presented allow an understanding of the transference of knowledge by means of a regulation process supported in earlier competences. In this case, it can be said that plans were redeveloped resulting in a successful operating mode.

By studying the diverse resources that are mobilized, integrated and transferred in this process, which are materialized in work activity, we can identify the competence in action. The farmer used the competence and abilities he had with respect to cow's milk production, adopted his knowledge to the new goat milk production situation, modified his resources based on observed variables such as the distinct behavior of the animal species, the physiological cycle of these animals, the cost and efficiency of the systems for work activity

\section{Conclusions}

The conceptual support proposed for this study initially was based on Le Boterf $(1995,2004)$. However, when citing sources of knowledge used by workers, he does not relate them to operating modes or deepen the discussion on the cognitive processes mobilized during the development of competencies.

Given this finding, which occurred during data analysis, the need to include in the model the meaning of the farmers' activities was identified. In fact, it is these activities that make the worker's knowledge and abilities operational. They materialize the located and finalized operating modes resulting from operating strategies. The observation of the effects of the actions taken on the work system and the results achieved provide feedback to the abilities and knowledge of the subject, consolidating his experience. When the actions are effective and the results are those expected, the strategies and operating modes are consolidated. When there is partial effectiveness or failure, the farmer tends to develop new strategies and new operating modes by means of corrective action. This process makes possible the evolution and development of new competences and the perfection of already validated competences.

One of the issues the study explored was the evolution of competences in relation to what was prescribed and what was effective (real), illustrated by the example of the farmer's decision-making process. It can be seen that in changing the drug dosage from one type of animal to another, he did so by trial and error, one of the modalities of heuristic reasoning, going against the prescription given by the veterinarian. This example reflects the evolution of a consolidated competence in a new situation, making explicit the reasoning that guided the action explicit and how the logic that guides the action is constructed.

From this perspective the interesting question is how the indicators that lead to a decision or to adopting a certain operating mode are structured. Activity analysis is a precious tool that reveals the parameters that are prioritized vis-à-vis the prescription. It is in this process that competence is built, when the farmer uses the knowledge of the results of an action to overcome obstacles to achieving a goal, and modifies his activity by integrating new knowledge that permits him to redefine the action strategy.

The strategies and operating modes involved in developing competences are determinants in comprehending how the cognitive processes are organized. This procedure allows for the inclusion 
of mechanisms that preserve the opportunity to observe the significant variables in the management of variability and to define the actions workers must perform. In intervening, for example, in the spatial arrangement of the present situation to transform it, one can maintain what is effective for the work and improve aspects that cause the farmers difficulty.

Moreover, comprehending how the competences are structured allows for the development of training compatible with the workers' representations of their realities. Thus, one can encourage the integration of new knowledge of a declarative nature with the resources of a procedural nature that are part of the subjects' experience.

\section{References}

Abrahão, J., Sznelwar, L., Silvino, A., Sarmet, M., \& Pinho, D. (2009). Introdução à Ergonomia: da teoria à prática. São Paulo: Blücher.

Darré, J. P. (1989). Le rôle des groupes de voisinage dans l'élaboration et la reproduction des normes de travail. In France, Ministère de l'Agriculture. Bulletin Technique d'Information (Vol. 442-443, pp. 353-358). Paris.

Dejours, C. (2012). Sexualidade e trabalho (Trabalho Vivo, Tomo 1.). Brasília: Paralelo 15.

Guérin, F., Laville, A., Daniellou, F., Duraffourg, J., \& Kerguelen, A. (2001). Compreender o trabalho para transformá-lo. São Paulo: Blücher.

Jourdan, M. (1989). Développement technique sur l'exploitation agricole et compétences de l'agriculteur
(Bulletin Technique d'Information, No. 442-443, pp. 335-344). Paris: Ministère de l'Agriculture.

Le Boterf, G. (1995). De la compétence: essai sur un attracteur étrange (4th ed.). Paris: Les Éditions d'Organisation.

Le Boterf, G. (2004). Construire les compétences individuelles et collectives: la compétence n'est plus ce qu'elle était (3rd ed.). Paris: D'Organisation.

Leplat, J. (2001). Compétence et ergonomie. In J. Leplat \& M. Montmollin (Eds.), Les competences en ergonomie (pp. 41-53). Toulouse: Octarès Éditions.

Maggi, B. (2004). Do agir organizacional. São Paulo: Blücher.

Montedo, U. B., \& Sznelwar, L. 1. (2008) Análise ergonômica do trabalho agrícola familiar. Produção, 18(1), 142-154. http://dx.doi.org/10.1590/S0103-65132008000100011

Montedo, U. B., \&t Sznelwar, L. 1. (2009). The tacit relationship between ergonomic work analysis and the theory of complexity. In Proceedings of the 17th Triennial Congress of the International Ergonomics Association, Beijing, China. [CD-ROM]. Beijing: IEA.

Montmollin, M. (2001). La competence. In J. Leplat \& M. Montmollin (Eds.), Les competences en ergonomie (pp. 11-25). Toulouse: Octarès Éditions.

Oliveira, C. L. M. (2013, Mar 19). Febre do leite. Belo Horizonte: EMATER-MG. Retrieved from http://www. emater.mg.gov.br/portal.cgi?flagweb=site_tpl_paginas internasctid $=9122$

Teiger, C. (1993). Représentation du travail et travail de la représentation. In A. Weill-Fassina, P. Rabardel \& D. Dubois (Eds.), Représentations pour l'action (pp. 311334). Toulouse: Octarès Éditions.

Weill-Fassina, A., \& Pastré, P. (2007). As competências profissionais e seu desenvolvimento. In Falzon, P. (Ed.), Ergonomia. (pp. 175-191). São Paulo: Blücher. 